\title{
Guided therapy in patients with acute heart failure: left ventricular diastolic filling pattern and NT-proBNP
}

\author{
Akut kalp yetmezlikli hastalarda kılavuz tedavi: sol ventrikül doluş bulguları \\ ve NT-proBNP
}

\author{
(D) Ersin Sarıçam ${ }^{1}$, (D) Arslan Öcal ${ }^{2}$ \\ ${ }^{1}$ Atılım University, School of Medicine, Medicana International Ankara Hospital, Department of Cardiology, Ankara, Turkey \\ ${ }^{2}$ University of Health Sciences, Gülhane Training and Research Hospital, Department of Cardiology, Ankara, Turkey
}

Cite this article as / Bu makaleye atıf için: Sarıçam E, Öcal A. Guided therapy in patients with acute heart failure: left ventricular diastolic filling pattern and NT-proBNP. J Health Sci Med 2020; 3(3): 285-290.

\begin{abstract}
Aim: N-terminal pro B-type natriuretic peptide has been commonly used in acute heart failure. We investigated whether the Doppler transmitral flow parameters on admission and discharge offer a useful guide like $\mathrm{N}$-terminal pro B-type natriuretic peptide levels in acute heart failure.

Material and Method: This study with a prospective randomized design included 57 patients admitted to the emergency department between October 2019 and March 2020. All patients had New York Heart Association class IV, had sinus rhythm, and were diagnosed previously with dilate cardiomyopathy. The left ventricular diastolic filling pattern during admission and discharge was evaluated in all patients using transthoracic echocardiography. $\mathrm{N}$-terminal pro B-type natriuretic peptide levels were analyzed on admission and discharge to compare the left ventricular filling pattern.

Results: The average age of the patients was $64.94 \pm 5.56$ years. During admission, the left ventricular filling pattern of all patients was of restrictive type (type III), whereas during discharge, 46 patients had abnormal relaxation (type I) and 11 patients had pseudonormal (type II) filling pattern. N-terminal pro B-type natriuretic peptide levels were $8004.75 \pm 743 \mathrm{pg} / \mathrm{mL}$ and $1645.17 \pm 104.58 \mathrm{pg} / \mathrm{mL}$ during admission and discharge, respectively. The mean e/e' ratio of the patients was $14.83 \pm 0.25$ and $7.70 \pm 0.14$ and $\mathrm{E} / \mathrm{A}$ ratio was $2.51 \pm 0.35$ and $1.42 \pm 0.33$ during admission and discharge, respectively. N-terminal pro B-type natriuretic peptide levels with regard to the mitral filling pattern were different during discharge. The N-terminal pro B-type natriuretic peptide level with an abnormal relaxation pattern was $1440.43 \pm 144.75 \mathrm{pg} / \mathrm{mL}$ and that with a pseudonormal pattern was $1957.60 \pm 64.00 \mathrm{pg} / \mathrm{mL}(\mathrm{p}=0.003)$.

Conclusion: Our study demonstrated that the left ventricular filling pattern successfully guided in acute heart failure therapy, similar to $\mathrm{N}$-terminal pro B-type natriuretic peptide -guided therapy.
\end{abstract}

Keywords: Acute heart failure, left ventricular filling pattern, guided therapy

ÖZ

Amaç: N-terminal pro B tip natriüretik peptid akut kalp yetmezliğinde sıklıkla kullanılır. Bu çalısmada, akut kalp yetmezlikli hastaların Doppler transmitral akım parametrelerinin hastaneye kabul ve taburculukta N-terminal pro B tip natriüretik peptid gibi faydalı bir yaklaşım olup olamayacağını araştırdık.

Gereç ve Yöntem: Prospective randomize tasarlanan bu çalışma Ekim 2019-Mart 2020 arası acil bölümüne kabul edilen 57 hastaya kapsamaktadır. Tüm hastalar New York Heart Association sınıf IV olup sinüs ritminde ve önceden dilate kardiyomiyopati tanısı almışlardı. Hastalara giriş ve taburculukta transtorasik ekokardiyografi ile sol ventrikül diyastolik doluş paternleri değerlendirildi. Giriş ve çıkış N-terminal pro B tip natriüretik peptid seviyeleri sol venrtrikül doluş bulguları ile karşılaştırıldı.

Bulgular: Ortalama yaş $64,94 \pm 5,56$ idi. Girişte tüm hastaların sol ventrikül doluş paternleri restriktif tip doluş bozukluğu idi. Taburculukta 46 hasta anormal relaksasyon bozukluğu (Tip I), 11 hasta pseudonormal doluş bozukluğu (Tip II) vardı. N-terminal pro B tip natriüretik peptid seviyeleri girişte $8004,75 \pm 743 \mathrm{pg} / \mathrm{mL}$, taburculukta $1645,17 \pm 104,58 \mathrm{pg} / \mathrm{mL}$ idi. Ortalama e/e' oranı girişte $14,83 \pm 0,25$ taburculukta 7,70 $\pm 0,14$ idi. Ortalama E/A oranı girişte $2,51 \pm 0,35$ taburculukta $1,42 \pm 0,33$ idi. Anormal relaksasyon tipte N-terminal pro B tip natriüretikpeptidseviyeleri $1440,43 \pm 144,75 \mathrm{pg} / \mathrm{mL}$, oysa pseudonormal pattern de $\mathrm{N}$-terminal pro B tip natriüretik peptid seviyeleri $1957,60 \pm 64,00 \mathrm{pg} / \mathrm{mL}(\mathrm{p}=0,003)$.

Sonuç: Akut kalp yetmezlikli hastalarda sol ventrikül doluş paternleri N-terminal pro B tip natriüretik peptid rehberliği gibi başarılı bir şekilde kullanılabileceğini göstermiştir.

Anahtar Kelimeler: Akut kalp yetmezliği, sol ventrikül doluş bulguları, kılavuz tedavi 


\section{INTRODUCTION}

Acute heart failure (AHF), a life-threatening medical condition, needs immediate evaluation and treatment (1). Moreover, it is the leading cause of hospital admission among patients above 65 years of age and accounts for $3 \%$ of the total national health care budget, $70 \%$ of which comes from hospitalization (2). Therefore, there is a need for reliable indicators for effective and immediate treatment.

In the emergency department and intensive care unit (ICU), N-terminal pro B-type natriuretic peptide (NTproBNP) has been generally used in dyspneic patients. It accurately indicates heart failure severity and is well associated with New York Heart Association (NYHA) classification functional class $(3,4)$. Moreover, it consistently predicts one-year mortality in patients with AHF (5). In addition, NT-proBNP-guided therapy in AHF has been recently used in hospital guidance (6). Similarly, the transthoracic echocardiography (TTE) has also been commonly used to identify patients with acute dyspnea. Previous studies have shown that left ventricular diastolic filling patterns provide additional information for the stratification of the prognosis in patients with decompensated AHF $(7,8)$. We investigated whether Doppler transmitral flow parameters on admission and discharge are a useful guide like NT-proBNP levels.

\section{MATERIAL AND METHOD}

This study was approved by the university /local human research ethics committee and all procedures performed in studies involving human participants were in accordance with the ethical standards of the institutional and/or national research committee and with the 1964 Helsinki Declaration and its later amendments or comparable ethical standards. The study was carried out with the permission of Medicana International Ankara Hospital Ethics Committee (Permission granted / Decision number: 2019/5).

Patients with progressive resting dyspnea associated with the clinical signs of pulmonary and/or peripheral congestion were diagnosed with AHF after reviewing the chest radiograph, electrocardiogram (ECG), and echocardiogram. The clinical history, physical examination, blood biochemistry results, and ECG and chest radiographic findings of patients were recorded. All patients had NYHA class IV, sinus rhythm, and were diagnosed previously with dilated cardiomyopathy (reduced ejection fraction $[\mathrm{EF}],<35 \%$ ). After emergency treatment (oxygen, intravenous furosemide), the patients were admitted to ICU. We investigated whether Doppler transmitral flow parameters on admission and discharge are a useful guide like NT-proBNP levels ( $>30 \%$ reduction from admission to discharge). The complete clinical examination, Doppler echocardiography evaluation, and NT-proBNP analysis were performed in all patients after admission on day 3 .

The patients were excluded if they had atrial fibrillation, permanent pacemaker rhythm, chronic renal failure, severe valve disease requiring surgical intervention, and acute ischemia-induced decompensated AHF.

\section{Echocardiographic Measurements}

Standard TTE was performed in the left lateral decubitus position using Philips Affiniti 50G device (Philips, USA) with a $2.5 \mathrm{MHz}$ transducer to examine two-dimensional images (2-D) and evaluate $\mathrm{M}$-mode and Doppler values. In operation, depth was $20 \mathrm{~cm}$ and dynamic range was 6 . M-mode and 2-D images of the left ventricle and Doppler parameters were recorded on the basis of the American Society of Echocardiography (ASE) criteria (9).

Mitral valve prolapse and $\mathrm{P}$ wave dispersion (PWD) were obtained from the apical four-chamber view with a 5-mm PWD sample volume placed distal (5 to $10 \mathrm{~mm}$ ) to the mitral annulus between the mitral valve leaflets. All PWD values were recorded at $100 \mathrm{~mm} / \mathrm{s}$ and enhanced to maximize the signal on the screen, eliminate excess gain, and minimize wall filters; only end-expiratory signals were analyzed. Patients were instructed to perform the Valsalva maneuver, which they had practiced at least once. Mitral valve inflow and PWD were then recorded during the Valsalva maneuver. The Valsalva maneuver test was repeated up to three times to obtain adequate signals. In addition, a full clinical echocardiogram was obtained. M-mode echocardiographic recordings (parasternal long-axis view) were used to calculate left ventricle (LV) size, wall thickness, and mass and fractional shortening. The LV volumes and EF were measured using Simpson's biplane method from the apical four- and two-chamber views. The left atrium (LA) area was measured in the apical four-chamber view at end-systole.

\section{Differentiation Between Diastolic Filling Patterns}

LV filling pressures and diastolic function grade can be determined reliably using a few simple echocardiographic parameters with high feasibility (10).

According to the ASE and the European Association of Cardiovascular Imaging (EACVI) guidelines, diastolic filling patterns were categorized as normal, grade I (abnormal relaxation), grade II (pseudonormal), and grade III (restrictive filling). The recommended four variables and their abnormal cutoff values were as follows: annular e' velocity (septal e' $<7 \mathrm{~cm} / \mathrm{sec}$, lateral $\mathrm{e}^{\prime}<10 \mathrm{~cm} / \mathrm{sec}$ ), average E/e' ratio of $>14$, LA maximum volume index of $>34 \mathrm{~mL} / \mathrm{m} 2$, and peak tricuspid (TR) velocity of $>2.8 \mathrm{~m} / \mathrm{sec}(10)$. In addition, early (E) and late (A) peak filling velocities and E-wave deceleration time (DT) were identified. 
The normal filling was defined as following: mitral E/A ratio of $\geq 0.8$, average e/e' ratio of $<10$, normal LA volume index, peak TR velocity $(\mathrm{m} / \mathrm{sec})<2.8$, and DT between 0.14 and 0.23 second.

Grade I diastolic dysfunction has been defined as E/A ratio of $\leq 0.8$, peak E velocity of $\leq 50 \mathrm{~cm} / \mathrm{sec}$, average e/ ratio of $<10$, and normal or increased LA volume index.

Grade II diastolic dysfunction has been defined as mitral E/A ratio of $>0.8$ to $<2$, average e/e' ratio of $10-14$, peak TR velocity $(\mathrm{m} / \mathrm{sec})>2.8$, and increased LA volume index.

Grade III diastolic dysfunction has been defined as follows: mitral E/A ratio of $>2$, e/e' ratio of $>14$, peak TR velocity $(\mathrm{m} / \mathrm{sec})>2.8$, and elevated LA volume index. DT is typically short in these patients $(<160 \mathrm{msec})$; however, it can exceed $160 \mathrm{msec}$ in some patients in the presence of an E velocity of $>120 \mathrm{~cm} / \mathrm{sec}$, as it takes a longer time for a higher $\mathrm{E}$ velocity to decelerate.

Grade I diastolic filling has a normal left ventricle pressure, grade II has a moderate increase in filling pressure, and grade III has a marked elevation in filling pro-B-type (10). Cardiac filling pressures were found to improve if a change from restrictive to nonrestrictive pattern or from fusion to nonrestrictive pattern was noted after assessing with Doppler echocardiography between admission day and day 3.

\section{Measurement of NT-proBNP Plasma Levels}

$\mathrm{N}$-terminal pro B-type natriuretic peptide was measured by collecting $5 \mathrm{~mL}$ of whole blood into tubes containing potassium ethylenediaminetetraacetic acid $(1 \mathrm{mg} / \mathrm{mL}$ blood) upon admission and on the third day. Plasma NTproBNP was measured using the Immulite NT-proBNP assay $(\mathrm{pg} / \mathrm{mL})$.

\section{Statistical Analysis}

Continuous variables are presented as means (standard deviation, SD). Moreover, NT-proBNP levels, e/e' ratio, and $\mathrm{E} / \mathrm{A}$ ratio before and after treatment were estimated using the Mann-Whitney U-test. A p-value of less than 0.05 was considered significant.

\section{RESULTS}

The clinical characteristics of the patients on admission are shown in Table 1. The study group consisted of 57 patients (the average age of the patients was $64.94 \pm 5.56$ years). The study group included 41 men $(72 \%)$ and 16 women (28\%). Among all the patients, $14(24.6 \%)$ had ischemic dilated cardiomyopathy and 43 (75.4\%) nonischemic dilated cardiomyopathy.

\begin{tabular}{|c|c|}
\hline Age & $64.94 \pm 5.56$ \\
\hline Gender & male $41(72 \%)$, female 16 \\
\hline Electrocardiogram & Sinus rhythm, 57 (100\%) \\
\hline Ischemic dilated cardiomyopathy & $14(24.6 \%)$ \\
\hline Non-ischemic dilated cardiomyopathy & $43(75.4 \%)$ \\
\hline \multicolumn{2}{|c|}{ Admission medication, number (percentage) } \\
\hline Aspirin & $52(91.2 \%)$ \\
\hline Clopidogrel & $17(29.8 \%)$ \\
\hline Oral anticoagulation & $6(10.5 \%)$ \\
\hline Beta-blocker & $54(94.7 \%)$ \\
\hline ACE inhibitor & $40(70.2 \%)$ \\
\hline Angiotensin II receptor blocker & $7(12.3 \%)$ \\
\hline Sacubitril/valsartan & $10(17.5 \%)$ \\
\hline Diuretics & $57(100 \%)$ \\
\hline Aldosterone antagonist & $50(87.7 \%)$ \\
\hline Digoxin & $25(43.6 \%)$ \\
\hline Nitrates & $18(31.6 \%)$ \\
\hline ICD pacemaker & $45(78.9 \%)$ \\
\hline
\end{tabular}

During admission, 40 patients (70.2\%) were on angiotensin-converting enzyme inhibitors, 7 on angiotensin II receptor blocker, 10 (17.5\%) on Sacubitril/ valsartan, $57(100 \%)$ on diuretics, and $25(26 \%)$ on beta-blockers. Moreover, 45 patients had implantable cardioverter-defibrillator pacemakers. A delay of $3.4 \pm 2.8$ $\mathrm{h}$ was noted between admission and the first Doppler echocardiography.

A comparison of findings during presentation and discharge is shown in Table 2.

\begin{tabular}{|c|c|}
\hline \multicolumn{2}{|l|}{ At presentation } \\
\hline NT-proBNP levels $(\mathrm{pg} / \mathrm{mL})$ & $8004.75 \pm 743 \mathrm{pg} / \mathrm{mL}$ \\
\hline \multicolumn{2}{|l|}{ Echocardiography results } \\
\hline Diastolic diameter (mm) & $62.04 \pm 3.07$ \\
\hline Left atrium diameter $(\mathrm{mm})$ & $45.77 \pm 1.23$ \\
\hline Ejection fraction $(\mathrm{EF})$ & $24.13 \pm 2.63$ \\
\hline \multicolumn{2}{|l|}{ Pulsed Doppler (PWD) } \\
\hline E wave amplitude & $75.21 \pm 7.9$ \\
\hline A wave amplitude & $28.22 \pm 3.9$ \\
\hline Deceleration time (DT) & $62.88 \pm 13.96$ \\
\hline E/A ratio (57 patients) & $2.51 \pm 0.35$ \\
\hline $\mathrm{E} / \mathrm{e}^{\prime}$ & $14.83 \pm 0.25$ \\
\hline NYHA function class & IV \\
\hline \multicolumn{2}{|l|}{ At discharge } \\
\hline NT-proBNP levels (pg/mL) & $1645.17 \pm 104,58$ \\
\hline \multicolumn{2}{|l|}{ Pulsed Doppler (PWD) } \\
\hline E wave amplitude & $58.5 \pm 5.69$ \\
\hline A wave amplitude & $42.56 \pm 7.19$ \\
\hline Deceleration time (DT) & $136.64 \pm 8.81$ \\
\hline E/A ratio (46 patients) & $1.40 \pm 0.33$ \\
\hline $\mathrm{E} / \mathrm{e}^{\prime}$ & $7.70 \pm 0.14$ \\
\hline NYHA function class & II \\
\hline
\end{tabular}


NT-proBNP levels were $8004.75 \pm 743 \mathrm{pg} / \mathrm{mL}$ and $1645.17 \pm 104.58 \mathrm{pg} / \mathrm{mL}$ during admission and discharge, respectively. Patients had NYHA class IV during admission and class II during discharge. The mean e/ $\mathrm{e}^{3}$ ratio of the patients was $14.83 \pm 0.25$ and $7.70 \pm 0.14$ and E/A ratio was $2.51 \pm 0.35$ and $1.42 \pm 0.33$ during admission and discharge, respectively (Figure 1a, 1b, 1c).

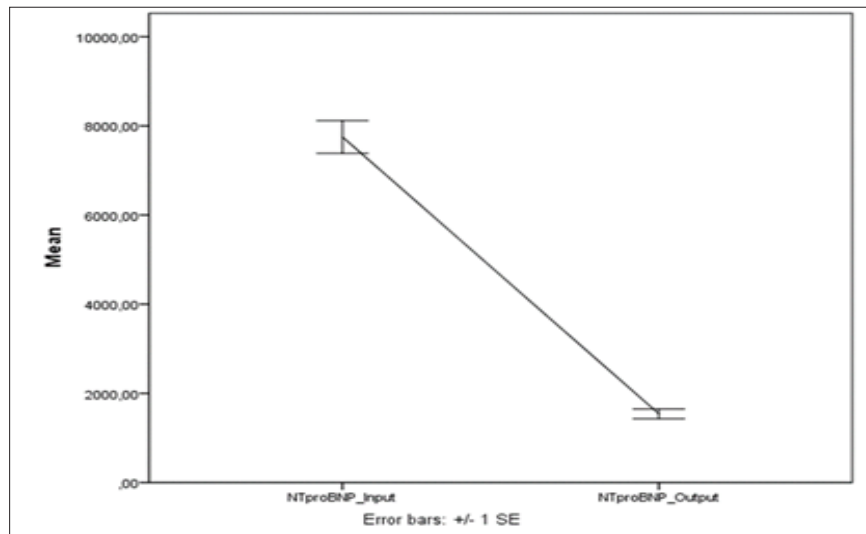

Figure 1a. NT-proBNP levels, E/e' ratio and E/A ratio before (input) and after (output) the treatment in relation to the successful treatment: $\mathrm{a}=$ NT-proBNP levels (input-output).

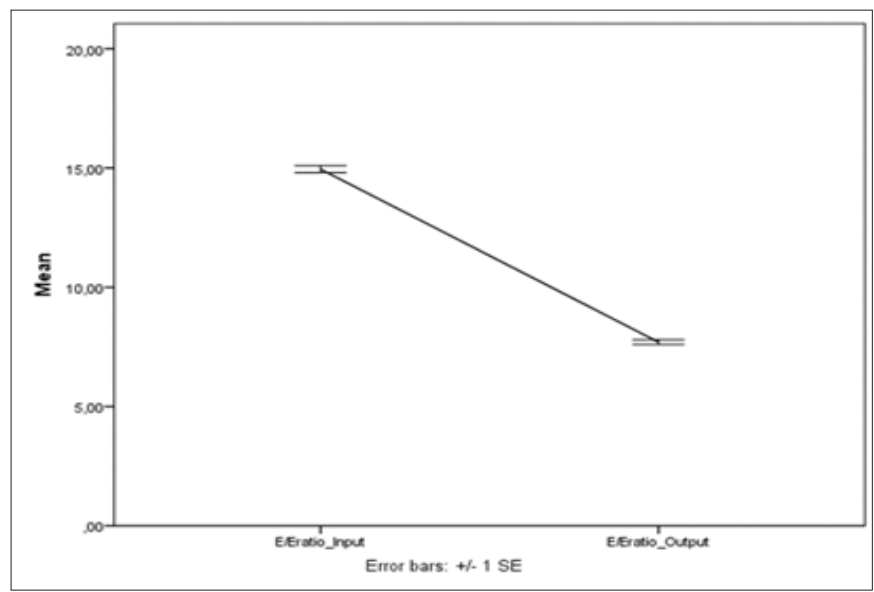

Figure 1b. NT-proBNP levels, E/e' ratio and E/A ratio before (input) and after (output) the treatment in relation to the successful treatment: $\mathrm{b}=\mathrm{E} / \mathrm{e}^{\prime}$ ratio (input-output).

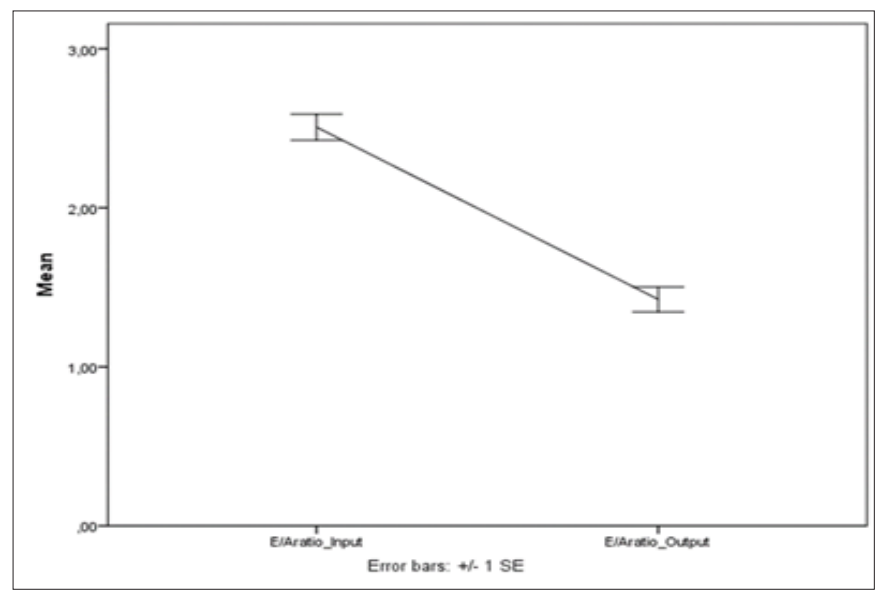

Figure 1c. NT-proBNP levels, E/e' ratio and E/A ratio before (input) and after (output) the treatment in relation to the successful treatment; $c=E / A$ ratio (input-output).
On admission, the mitral filling patterns of all the patients were restrictive filling (grade III). According to the discharge mitral filling pattern, the patients were divided into two groups: 1 . changed toward relaxation abnormality and 2 . changed toward pseudonormal. We then compared the changes in echo parameters. Among all the patients, 46 had abnormal relaxation (grade I) and 11 were pseudonormal (grade II). According to the discharge mitral filling pattern, NT-proBNP levels were different. NT-proBNP level with an abnormal relaxation pattern was $1440.43 \pm 144.75 \mathrm{pg} / \mathrm{mL}$ and that with a pseudonormal pattern was $1957.60 \pm 64.00 \mathrm{pg} / \mathrm{mL}$ $(\mathrm{p}=0.003$; Figure 2).

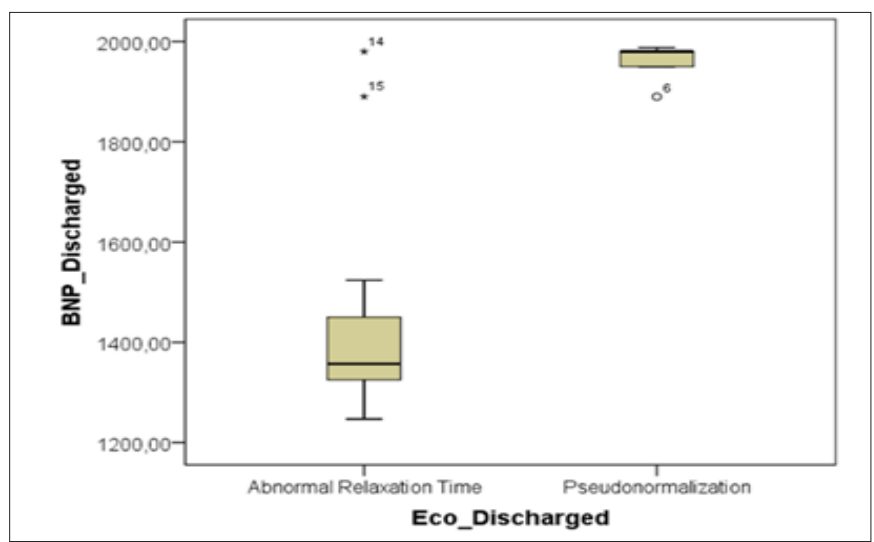

Figure 2. The comparison of discharge NT-proBNP levels according to the left ventricle diastolic filling pattern

\section{DISCUSSION}

AHF may occur frequently as a consequence of acute decompensation of chronic heart failure (1). Hospitalization and readmissions have increased the financial burden (2). Therefore, reliable indicators for effective treatment are needed. When considering the left ventricular function, $\mathrm{LV}$ end-diastolic pressure (LVEDP) is the most suitable pressure to be used (11). Moreover, LVEDP has been commonly used to assess LV diastolic function (12). LV diastolic functions provide crucial information in estimating LV filling pressures (13). Therefore, known abnormality of LVEDP has clinical importance.

The diastolic function in echocardiographic measurements reflects tissue changes, thus providing crucial prognostic information. According to ASE and EACVI, the left ventricular filling pressures can be estimated by the findings of LV diastolicfunction. LV filling pressures and diastolic function grade can be determined consistently using a few simple echocardiographic parameters with high feasibility (10). Echocardiographyguided therapy was performed in previous studies on the basis of sequential echocardiograms to evaluate hemodynamically derived parameters. Rohde et al.(14) 
showed that echocardiography-based therapy was a practical and useful technique for treating heart failure. Moreover, a meta-analysis of 12 post-acute myocardial infarction studies reported that restrictive filling is a crucial independent predictor of mortality after acute myocardial infarction, regardless of LVEF, end-systolic volume index, and Killip class (7).

Although NT-proBNP-guided therapy in patients with chronic heart failure was not more effective than a usual care strategy in improving outcomes, the PRIMA II trial revealed that the guidance of heart failure therapy to reach an NT-proBNP reduction of $>30 \%$ after clinical stabilization did not improve six-month outcomes $(6,15)$. In addition, the GUIDE-IT trial results did not reveal any benefit from a biomarker-guided strategy. However, the authors encouraged more real-life studies (16).

We monitored the left ventricular diastolic filling pattern in patients with decompensated AHF in hospital guidance like NT-proBNP-guided therapy. On admission, NT-proBNP levels were significantly high in patients $(8004.75 \pm 743 \mathrm{pg} / \mathrm{mL})$ and the mitral filling pattern was restrictive (grade III). Moreover, Pinamonti et al. (17) reported that the restrictive filling pattern can play a crucial role in predicting cardiac mortality in patients with dilated cardiomyopathy and congestive heart failure. The initial Doppler diastolic pattern was restrictive filling as expected because the restrictive pattern is closely associated with increased LVEDP. Thus, patients with restrictive filling have a higher LVEDP and higher adverse event rate (8). After effective heart failure therapy, the mitral Doppler diastolic filling pattern and NT-proBNP levels were studied again in ICU. During discharge from ICU, NT-proBNP levels were $1645.17 \pm 104.58 \mathrm{pg} / \mathrm{mL}$ and the mitral filling pattern was predominance grade I (46 patients) and lower grade II filling pattern (11 patients). Grade I filling pattern has normal LVEDP that is associated with clinical and symptomatic improvement. During admission and discharge, the enhancement from class IV to class II of NYHA functional class is related to LVEDP difference. According to the discharge mitral filling pattern, NT-proBNP levels in the patients were different. The NT-proBNP level with an abnormal relaxation pattern was $1440.43 \pm 144.75 \mathrm{pg} / \mathrm{mL}$ and that with a pseudonormal pattern was $1957.60 \pm 64.00 \mathrm{pg} /$ $\mathrm{mL}(\mathrm{p}=0.003)$. The difference can be explained as the pseudonormal pattern had higher LVEDP than the abnormal relaxation pattern.

Study limitations: Invasive measurements of the LVEDP might be more confirmative for the hypothesis that these findings reflect an incrementally higher LVEDP in each group.

\section{CONCLUSION}

During admission and discharge, the left ventricular diastolic filling pattern in decompensated AHF might be used as clinical monitoring like NT-proBNP-guided therapy.

\section{ETHICAL DECLARATIONS}

Ethics Committee Approval: The study was carried out with the permission of Medicana International Ankara Hospital Ethics Committee ((Permission granted: 2019, Decision number: 2019/5). The study was conducted as per the principles of the Declaration of Helsinki.

Informed Consent: Written informed consent was obtained from all participants who participated in this study.

Referee Evaluation Process: Externally peer-reviewed.

Conflict of Interest Statement: The authors have no conflicts of interest to declare.

Financial Disclosure: The authors declared that this study has received no financial support.

Author Contributions: All of the authors declare that they have all participated in the design, execution, and analysis of the paper, and that they have approved the final version.

\section{REFERENCES}

1. Ponikowski P, Voors AA, Anker SD, et al. Authors/task force members. 2016 European Society of Cardiology (ESC) guidelines for the diagnosis and treatment of acute and chronic heart failure: the task force for the diagnosis and treatment of acute and chronic heart failure of the ESC developed with the special contribution of the Heart Failure Association (HFA) of the ESC. Eur Heart J 2016; 37: 2129-200.

2. Stevenson LW, Braunwald E. Recognition and management of patients with heart failure. In: Goldman L, Braunwald E, ed. Primary Cardiology. Philadelphia, PA: W.B. Saunders, 1998:31029.

3. Maisel A. B-type natriuretic peptide measurements in diagnosing congestive heart failure in the dyspneic emergency department patient. Rev Cardiovasc Med 2002; 3: 10-7.

4. Maisel AS, Krishnaswamy P, Nowak RM, et al. Rapid measurement of B-type natriuretic peptide in the emergency diagnosis of heart failure. N Engl J Med 2002; 347:161-7.

5. Noveanu M, Breidthardt T, Potocki M, et al. Direct comparison of serial B-type natriuretic peptide and NT-proBNP levels for prediction of short-and long-term outcome in acute decompensated heart failure. J Crit Care 2011; 15: 1.

6. Stienen S, Salah K, Moons AH, et al. NT-proBNP-guided therapy in acute decompensated heart failure: the PRIMA II randomized controlled trial. Circulation 2018; 137: 1671-83.

7. Møller JE, Whalley GA, Dini FL, et al. Meta-Analysis Research Group in Echocardiography (MeRGE) AMI Collaborators. Independent prognostic importance of a restrictive left ventricular filling pattern after myocardial infarction: an individual patient meta-analysis: Meta-Analysis Research Group in Echocardiography acute myocardial infarction. Circulation 2008; 117: 2591-8. 
8. Whalley GA, Doughty RN, Gamble GD, et al.Pseudonormal mitral filling pattern predicts hospital re-admission in patients with congestive heart failure. J Am Coll Cardiol 2002; 39: 1787-95.

9. Schiller NB, Shah PM, Crawford M, et al. Recommendations for quantitation of the left ventricle by two-dimensional echocardiography. American Society of Echocardiography Committee on standards, subcommittee on quantitation of twodimensional echocardiograms. J Am Soc Echocardiogr 1989; 2:358-67.

10. Nagueh SF, Smiseth OA, Appleton CP, et al. Recommendations for the evaluation of left ventricular diastolic function by echocardiography: an update from the American Society of Echocardiography and the European Association of Cardiovascular Imaging. J Am Soc Echocardiogr 2016; 29:277314 .

11. Peverill RE. "Left ventricular filling pressure(s)"-ambiguous and misleading terminology, best abandoned. Int J Cardiol 2015; 191: $110-3$.

12. Sharifov OF, Schiros CG, Aban I, Denney TS, Gupta H Diagnostic accuracy of tissue doppler index e/e' for evaluating left ventricular filling pressure and diastolic dysfunction/heart failure with preserved ejection fraction: a systematic review and metaanalysis. J Am Heart Assoc 2016; 5: e002530.

13. Balaney B, Medvedofsky D, Mediratta A, et al. Invasive validation of the echocardiographic assessment of left ventricular filling pressures using the 2016 diastolic guidelines: head-to-head comparison with the 2009 guidelines. J Am SocEchocardiogr 2018; 31: 79-88

14. Rohde LE, Palombini DV, Polanczyk CA, Goldraich LA, Clausell N. A hemodynamically oriented echocardiography-based strategy in the treatment of congestive heart failure. J Card Fail 2007; 13: 618-25.

15. Felker GM, Anstrom KJ, Adams KF, et al. Effect of natriuretic peptide-guided therapy on hospitalization or cardiovascular mortality in high-risk patients with heart failure and reduced ejection fraction: a randomized clinical trial. JAMA 2017; 318 : 713-20.

16. Ibrahim NE, Januzzi JL Jr. The future of biomarker-guided therapy for heart failure after the guiding evidence-based therapy using biomarker intensified treatment in heart failure (guide-it) study. Curr Heart Fail Rep 2018; 15: 37-43.

17. Pinamonti B, Zecchin M, Di Lenarda A, Gregori D, Sinagra G, Camerini F. Persistence of restrictive left ventricular filling pattern in dilated cardiomyopathy: an ominous prognostic sign. J Am Coll Cardiol 1997; 29: 604-12. 